\title{
PENGEMBANGAN LEMBAR KERJA SISWA BERBASIS PENDIDIKAN KARAKTER DALAM MATERI BANGUN RUANG SISI DATAR
}

\author{
Dian Asta Ekowaty Muku1, Syarifah Fadillah ${ }^{2}$, Rahman Haryadi ${ }^{3}$ \\ ${ }^{1,2,3}$ Program Studi Pendidikan Matematika Fakultas Pendidikan MIPA dan Teknologi \\ IKIP PGRI Pontianak, Jalan Ampera Nomor 88 Pontianak - 78116 \\ e-mail: dianasta04@gmail.com
}

\begin{abstract}
Abstrak
Tujuan penelitian adalah untuk mengetahui tingkat kevalidan dan kepraktisan lembar kerja siswa. Metode penelitian adalah penelitian dan pengembangan dengan menggunakan model rancangan 4D. Teknik pengumpulan data yang digunakan adalah teknik komunikasi langsung dan komunikasi tidak langsung. Alat pengumpul data yang digunakan adalah lembar validasi dan angket. Subjek uji coba penelitian yaitu siswa kelas VIII H SMP Negeri 1 Sintang sebanyak 31 siswa. Penelitian menghasilkan lembar kerja siswa berbasis pendidikan karakter yang memenuhi tingkat kevalidan dengan rata-rata skor penilaian validator sebesar 95,70\% dengan kriteria sangat valid. Setelah dilakukan uji coba, diperoleh data bahwa lembar kerja siswa berbasis pendidikan karakter memenuhi tingkat kepraktisan dengan rata-rata skor penilaian angket respons siswa sebesar $89,08 \%$ dengan kriteria sangat praktis dan angket respons guru sebesar $85,56 \%$ dengan kriteria sangat praktis. Hasil penelitian menunjukkan bahwa lembar kerja siswa berbasis pendidikan karakter memenuhi tingkat kevalidan dan kepraktisan.
\end{abstract}

Kata Kunci: lembar kerja siswa, pendidikan karakter, kevalidan, kepraktisan.

\begin{abstract}
The purpose of this study was to determine the level of validity and practicality of student worksheets. The research method was research and development using the $4 D$ design model. Data collection techniques used direct communication and indirect communication techniques. Data collection tools used validation sheets and questionnaires. The subjects of the research trial were 31 students of class VIII H of SMP Negeri 1 Sintang. The study produced a worksheet based on character education with the validity level an average score of $95.70 \%$ by the validators assessment with very valid criteria. After testing, the data obtained that character education-based student worksheets with the practicality level an average score of $89.08 \%$ by student response questionnaire score with very practical criteria and teacher response questionnaire of $85.56 \%$ with very practical criteria. The results showed that the worksheet based on character education comply the level of validity and practicality.
\end{abstract}

Keywords: student worksheets, character education, validity, practicality.

\section{PENDAHULUAN}

Pendidikan mempunyai peranan penting dalam meningkatkan dan mengembangkan kualitas sumber daya manusia. Melalui pendidikan, manusia dapat mengembangkan potensi yang dimiliki guna mencapai tujuan hidup yang diinginkan. Seperti yang tercantum dalam Peraturan Pemerintah Nomor 17 Tahun 
2010 tentang Pengelolaan Penyelenggaraan Pendidikan pada Pasal 17 Ayat (3) menyebutkan bahwa pendidikan dasar, termasuk sekolah bertujuan membangun landasan bagi berkembangnya potensi peserta didik agar menjadi manusia yang: (1) Beriman dan bertakwa kepada Tuhan Yang Maha Esa; (2) Berakhlak mulia dan berkepribadian luhur; (3) Berilmu, cakap, kritis, kreatif, dan inovatif; (4) Sehat, mandiri, dan percaya diri; dan (5) Toleran, peka, sosial, demokratis, dan bertanggung jawab (Fathurrohman, dkk., 2017).

Berdasarkan hal tersebut, jelas bahwa tujuan pendidikan di setiap jenjang pendidikan berkaitan dengan pembentukan karakter peserta didik (siswa). Tujuan tersebut dapat dioperasionalkan menjadi tujuan pembelajaran di sekolah melalui mata pelajaran yang diberikan. Salah satu mata pelajaran yang diberikan di sekolah adalah matematika. Matematika adalah mata pelajaran pokok yang diajarkan pada setiap jenjang pendidikan, mulai dari sekolah dasar hingga perguruan tinggi.

Depdiknas (Farapatana, dkk, 2019) menyatakan bahwa mata pelajaran matematika perlu diberikan kepada semua siswa mulai dari sekolah dasar hingga perguruan tinggi untuk membekali siswa dengan kemampuan berpikir logis, analitis, sistematis, kritis, dan kreatif, serta kemampuan bekerja sama. Dalam proses pembelajaran, matematika tidak hanya dipandang sebagai ilmu yang mementingkan kemampuan kognitif saja, tetapi juga berkaitan dengan pembentukan sikap dan perilaku yang terpuji. Oleh karenanya, pembelajaran matematika dapat dipandang sebagai suatu keadaan nilai yang berkaitan dengan pendidikan karakter. Sehingga, dalam belajar matematika diharapkan dapat mengembangkan karakter yang baik dalam diri siswa. Ryan dan Bohlin (Nuhamara, 2018) berpendapat bahwa karakter yang baik adalah tentang mengetahui apa yang baik, mencintai yang baik, dan melakukan apa yang baik. Namun pada kenyataannya harapan tersebut tidak sesuai dengan keadaan yang terjadi. Karakter-karakter yang baik tersebut seharusnya terdapat dalam bahan ajar yang digunakan dalam proses pembelajaran.

Bahan ajar yang dikembangkan adalah lembar kerja siswa (LKS). Menurut Prastowo (Riskawati, dkk., 2018), LKS merupakan suatu bahan ajar cetak berupa 
lembar-lembar kertas yang berisi materi, ringkasan, dan petunjuk-petunjuk pelaksanaan tugas pembelajaran yang harus dikerjakan oleh siswa yang mengacu pada kompetensi dasar yang harus dicapai. Sedangkan, menurut Trianto (Annisa, 2017), LKS adalah panduan siswa yang digunakan untuk melakukan kegiatan penyelidikan atau pemecahan masalah. Berdasarkan pengertian tersebut, dapat disimpulkan bahwa LKS merupakan panduan untuk siswa yang berisi materi, ringkasan, dan tugas-tugas yang harus dikerjakan oleh siswa. Penggunaan LKS bertujuan untuk mempermudah siswa berinteraksi dengan materi yang diberikan, sehingga siswa dapat melatih kemandiriannya dalam belajar. Tugas-tugas yang disajikan dalam LKS dapat meningkatkan penguasaan siswa terhadap materi yang diberikan, serta dapat memudahkan guru dalam memberikan tugas-tugas kepada siswa (Prastowo dalam Khairunnisa, 2016).

LKS yang digunakan oleh guru di sekolah merupakan LKS yang hanya memuat soal-soal latihan secara berkelompok, tanpa dilengkapi dengan penyajian materi ajar, serta contoh-contoh soal dan penyelesaian. LKS tersebut juga belum memuat pendidikan karakter. Oleh karenanya, diperlukan pengembangan LKS berbasis pendidikan karakter dengan penyajian materi ajar yang sistematis, serta penyajian contoh-contoh soal dan penyelesaian. Sehingga, dapat mempermudah guru dalam menyampaikan materi ajar dengan baik dan dapat mendorong siswa secara aktif dalam memahami dan menguasai materi yang disampaikan, serta dapat memacu siswa untuk mengembangkan karakter yang baik dalam dirinya.

Mengacu pada pembahasan yang telah diuraikan, penelitian yang dilakukan berupaya untuk mengembangkan LKS berbasis pendidikan karakter. Menurut Ryan dan Bohlin (Sugiana, 2019), pendidikan karakter adalah upaya sungguhsungguh untuk membantu seseorang memahami, peduli, dan bertindak dengan landasan inti nilai-nilai etis. Ramli (Harahap, 2017) menyatakan bahwa pendidikan karakter memiliki esensi dan makna yang mirip dengan pendidikan moral. Pendidikan karakter penting dikembangkan dalam dunia pendidikan karena pendidikan karakter tidak hanya membuat seorang anak mempunyai akhlak yang mulia, tetapi juga dapat meningkatkan kualitas akademiknya (Fathurrohman, dkk., dalam Kesuma, 2018). Hakikat dari pendidikan karakter dalam konteks 
pendidikan di Indonesia adalah pendidikan nilai, yakni pendidikan nilai-nilai luhur yang bersumber dari karakter bangsa Indonesia dalam rangka membina kepribadian generasi muda.

LKS berbasis pendidikan karakter yang dikembangkan memerlukan sebuah model pembelajaran inovatif. Beberapa pakar pendidikan matematika telah mencoba mengkaji model-model pembelajaran yang dapat memacu siswa untuk mengembangkan karakter. Menurut Sujadi (Fadillah, 2013), pembelajaran dengan pendekatan kontekstual dengan berbagai model dan metodenya dapat dijadikan sebagai alat untuk membangun karakter bangsa. Prabowo dan Sidi (Ramadhani, 2017) menyatakan bahwa pendekatan pembelajaran matematika realistik (PMRI) dapat memahat karakter siswa. Model pembelajaran yang akan digunakan dalam penelitian yang dilakukan adalah model pembelajaran berbasis masalah (ProblemBased Learning). Model pembelajaran berbasis masalah adalah suatu pembelajaran yang menggunakan masalah dunia nyata sebagai suatu konteks bagi siswa untuk belajar tentang cara berpikir kritis dan keterampilan pemecahan masalah serta untuk memperoleh pengetahuan dan konsep yang esensial dari materi pembelajaran (Nurhasanah dalam Sumartini, 2015).

Model pembelajaran berbasis masalah memiliki ciri khas, yaitu sebagai sarana yang memfasilitasi terjadinya proses pembelajaran. Langkah-langkah dalam pembelajaran berbasis masalah, yaitu: (1) Orientasi siswa kepada masalah; (2) Mengorganisasi siswa; (3) Membimbing penyelidikan individu dan kelompok; (4) Mengembangkan dan menyajikan hasil karya; dan (5) Menganalisis dan mengevaluasi proses pemecahan masalah. Pada fase kedua, guru dapat mengingatkan siswa untuk bertanggung jawab terhadap hasil pekerjaannya dalam proses pemecahan masalah. Kemudian, pada fase ketiga guru dapat mengingatkan siswa untuk jujur dalam mengumpulkan informasi yang sesuai dan bekerja keras melaksanakan eksperimen dalam pemecahan masalah. Guru juga dapat memotivasi siswa agar disiplin dalam menyelesaikan masalah. Sehingga, melalui kegiatan-kegiatan dalam model pembelajaran berbasis masalah, karakter yang dapat dikembangkan adalah bertanggung jawab, jujur, kerja keras, dan disiplin. 
LKS yang dikembangkan memuat pendidikan karakter yang terdapat pada petunjuk kegiatan siswa dan uji kompetensi, contoh soal, serta beberapa soal pada uji kompetensi. Pendidikan karakter juga disajikan dalam bentuk kalimat motivasi. Oleh karenanya, LKS berbasis pendidikan karakter diharapkan mampu mengembangkan karakter yang baik dalam diri siswa.

\section{METODE}

Metode penelitian yang digunakan adalah research and development atau biasa disebut dengan metode penelitian dan pengembangan. Rancangan penelitian dan pengembangan yang digunakan adalah model 4D. Model 4D terdiri dari 4 tahapan pengembangan, yaitu Define, Design, Develop, dan Desseminate. Namun, penelitian yang dilakukan hanya sampai pada tahap Develop (tanpa tahap Desseminate).

Tahap pendefinisian (Define) bertujuan untuk menetapkan dan mendefinisikan syarat-syarat pembelajaran, yang meliputi: (1) Analisis awal-akhir yang digunakan untuk menetapkan masalah dasar yang dihadapi dalam pembelajaran sehingga diperlukan suatu pengembangan bahan ajar; (2) Analisis siswa yang digunakan untuk menelaah karakteristik siswa yang sesuai dengan desain (rancangan) pengembangan bahan ajar; (3) Analisis konsep yang digunakan untuk menentukan isi materi dalam bahan ajar yang dikembangkan; (4) Analisis tugas yang digunakan untuk menentukan isi suatu pengajaran dan merinci isi materi ajar dalam bentuk garis besar; (5) Perumusan tujuan pembelajaran yang digunakan untuk menentukan indikator tujuan pembelajaran yang didasarkan pada analisis tugas dan analisis konsep. Kemudian, peneliti menentukan subjek untuk melakukan uji coba dengan menggunakan teknik purposive sampling. Teknik purposive sampling digunakan dengan pertimbangan yang didasarkan pada rekomendasi dari guru mata pelajaran matematika.

Tahap perancangan (Design) dilakukan untuk merancang produk pengembangan yang disesuaikan dengan permasalahan yang diperoleh pada tahap pendefinisian, yang meliputi: (1) Penyusunan instrumen penelitian yang dilakukan untuk menilai kevalidan dan kepraktisan LKS. Penyusunan instrumen penelitian 
dibagi menjadi dua langkah, yaitu langkah pertama meliputi penyusunan kisi-kisi lembar validasi dan kisi-kisi angket dan langkah kedua meliputi penyusunan lembar validasi dan angket sesuai dengan kisi-kisi yang telah dibuat pada langkah pertama; (2) Pemilihan format yang dilakukan agar format yang dipilih sesuai dengan materi pembelajaran; dan (3) Rancangan awal merupakan rancangan LKS yang telah dibuat oleh peneliti kemudian dilakukan validasi dan uji coba.

Tahap pengembangan (Develop) bertujuan untuk menghasilkan produk yang telah direvisi berdasarkan komentar dan saran dari para ahli dan data hasil uji coba. Tahap pengembangan meliputi: (1) Validasi oleh ahli yang bertujuan untuk memvalidasi LKS berdasarkan komentar dan saran dari para ahli, sehingga layak untuk diujicobakan; (2) Uji coba yang dilakukan setelah LKS divalidasi oleh para ahli. Uji coba dilakukan untuk mengetahui kepraktisan LKS melalui angket respons guru dan siswa; dan (3) Produk akhir yang merupakan hasil dari perbaikan LKS berdasarkan komentar dan saran dari para ahli dan guru, kemudian dikemas dan dicetak sebagai produk akhir.

Subjek penelitian dalam penelitian terdiri dari ahli (validator), guru, dan siswa. Validator dalam penelitian adalah dosen Program Studi Pendidikan Matematika IKIP PGRI Pontianak yang berjumlah 3 orang. Satu orang guru sebagai responden merupakan guru mata pelajaran Matematika SMP Negeri 1 Sintang yang bertugas untuk mengisi lembar angket respons guru. Sedangkan, siswa sebagai subjek uji coba adalah siswa kelas VIII H SMP Negeri 1 Sintang yang berjumlah 31 orang.

Teknik pengumpulan data yang digunakan adalah teknik komunikasi langsung dan komunikasi tidak langsung. Teknik komunikasi langsung digunakan untuk memperoleh informasi terkait permasalahan yang terjadi, sedangkan teknik komunikasi tidak langsung digunakan untuk memperoleh penilaian terhadap kevalidan dan kepraktisan LKS. Nilai kevalidan ditentukan dengan kriteria minimal "Cukup Valid" dengan persentase 41\%-60\% dan nilai kepraktisan ditentukan dengan kriteria minimal "Cukup Praktis" dengan persentase 41\%-60\%.

Alat pengumpul data yang digunakan adalah lembar validasi dan angket. Angket yang digunakan adalah angket respons guru dan angket respons siswa. 
Lembar validasi digunakan untuk mengetahui penilaian ahli terhadap kevalidan LKS, sedangkan angket respons digunakan untuk mengetahui penilaian guru dan siswa terhadap kepraktisan LKS pada saat uji coba.

\section{HASIL DAN PEMBAHASAN}

Tahap pendefinisian (Define) bertujuan untuk memperoleh informasi tentang permasalahan yang terjadi untuk membantu peneliti dalam mengembangkan suatu produk. Pada tahap pendefinisian, peneliti menemukan masalah dalam pembelajaran matematika. Masalah tersebut diperoleh berdasarkan hasil wawancara pada pra-observasi dengan seorang guru mata pelajaran Matematika. Berdasarkan wawancara tersebut, diperoleh informasi bahwa selama proses pembelajaran matematika berlangsung, masih ada beberapa siswa yang memiliki karakter kurang baik, seperti tidak memperhatikan/acuh terhadap pembelajaran yang sedang dilaksanakan, saling mengobrol antara satu siswa dan siswa yang lainnya, tidak disiplin dalam menggunakan waktu selama mengerjakan soal-soal yang diberikan, serta bersikap tidak jujur, seperti menyontek pekerjaan teman dan mengerjakan soal-soal tersebut dengan tidak serius. Guru juga mengatakan bahwa susunan materi yang tumpang tindih dalam bahan ajar menjadi kendala dalam proses pembelajaran.

Langkah selanjutnya adalah peneliti menentukan materi dan kompetensi dasar (KD) yang akan digunakan dalam pengembangan bahan ajar (LKS). Materi yang digunakan adalah dua sub bab dari materi bangun ruang sisi datar. Pada sub bab pertama, memuat materi tentang luas permukaan kubus dan balok. Sedangkan, pada sub bab kedua memuat materi tentang luas permukaan prisma dan limas. Kemudian, kompetensi dasar dapat ditentukan sesuai dengan silabus kelas VIII semester genap. Kompetensi dasar yang diambil sebagai dasar penyusunan LKS adalah menentukan luas permukaan kubus, balok, prisma, dan limas. Langkah terakhir pada tahap pendefinisian adalah perumusan tujuan pembelajaran. Perumusan tujuan pembelajaran dilakukan agar siswa dapat mengembangkan karakter yang baik dalam dirinya melalui penggunaan LKS yang dikembangkan sebagai bahan ajar. Hal tersebut sesuai dengan penelitian Arahim 
(2018) yang melakukan identifikasi tujuan umum pembelajaran yang harus dicapai siswa dalam mengembangkan LKS.

Tahap perancangan (design) bertujuan untuk merancang produk pengembangan yang disesuaikan dengan permasalahan yang diperoleh di lapangan pada tahap pendefinisian. Pada tahap perancangan, langkah pertama yang dilakukan adalah dengan menyusun instrumen penelitian berupa kisi-kisi dan lembar validasi ahli materi; kisi-kisi dan lembar validasi ahli media; kisi-kisi dan angket respons guru; serta kisi-kisi dan angket respons siswa. Selanjutnya, peneliti melakukan pemilihan format untuk mendesain isi pembelajaran; pemilihan model pembelajaran dan sumber belajar; merancang isi LKS; dan membuat desain LKS yang meliputi desain layout, gambar, dan tulisan. Langkah terakhir dalam tahap perancangan adalah rancangan awal. Rancangan awal yang dimaksud adalah rancangan LKS yang telah dibuat oleh peneliti sebelum dilakukan validasi oleh ahli. Rancangan awal LKS yang telah dibuat dapat dilihat pada Gambar 1.

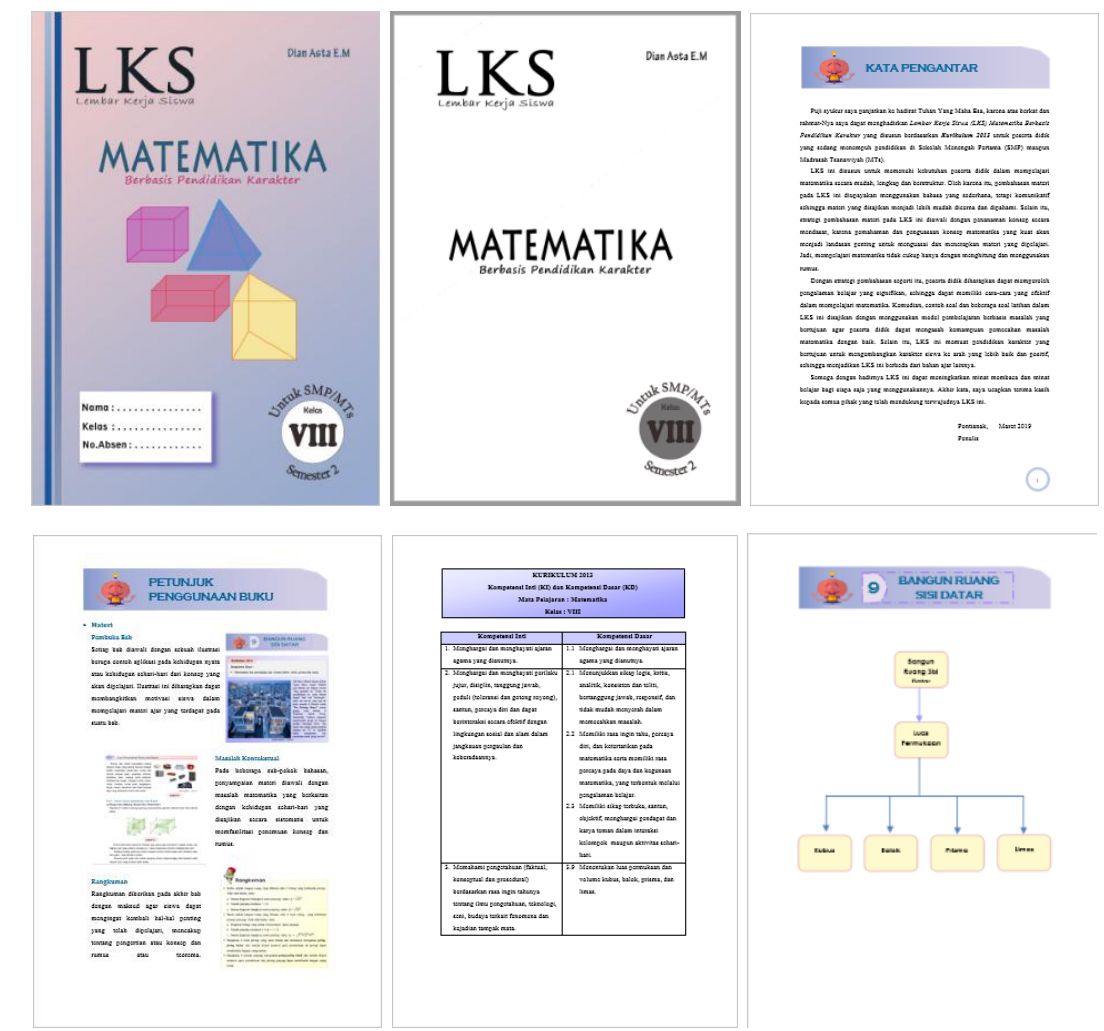




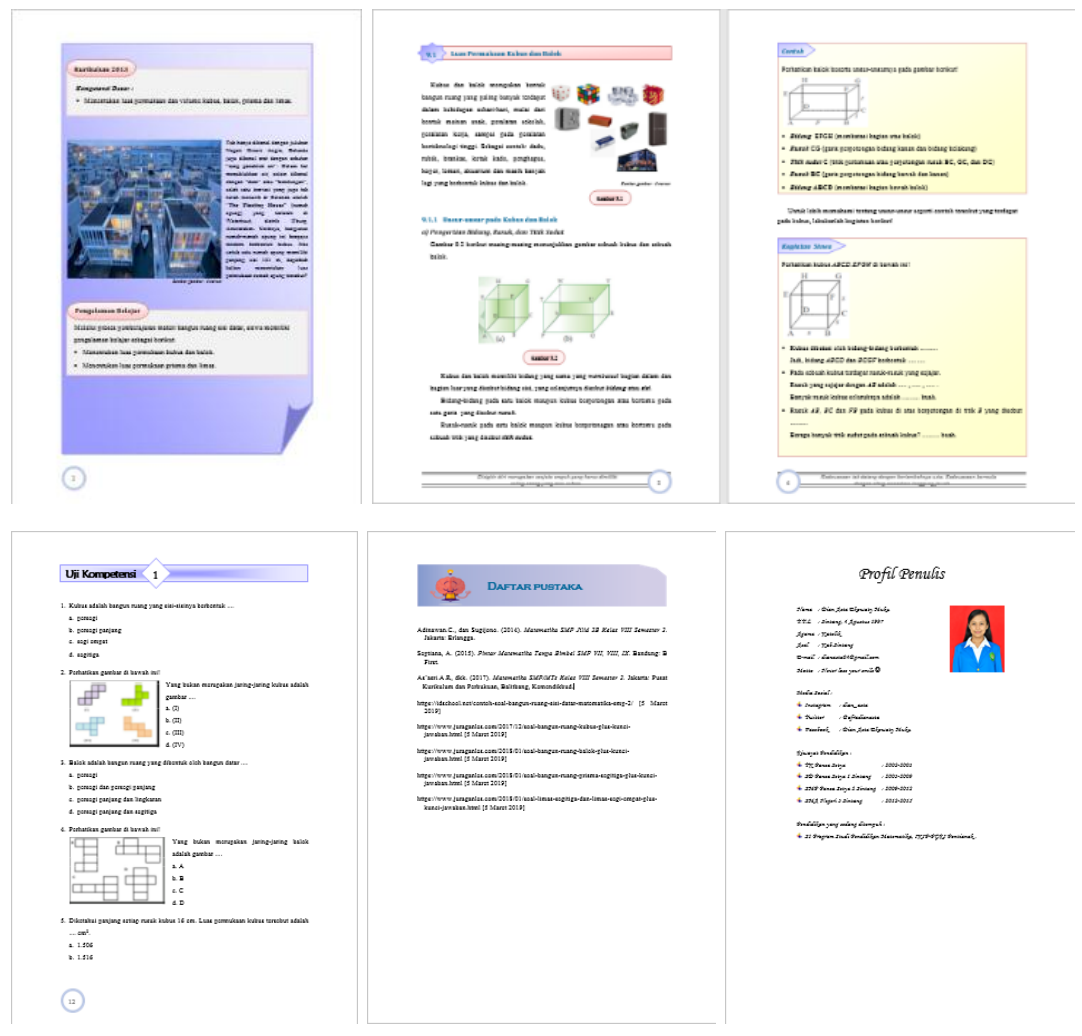

Gambar 1 Rancangan Awal LKS

Perbaikan LKS dilakukan berdasarkan komentar dan saran yang diberikan oleh guru pada saat uji coba. Hasil yang diperoleh dari perbaikan LKS untuk menjadi produk akhir yaitu: (1) Untuk menemukan luas permukaan kubus, balok, prisma, dan limas sebaiknya siswa yang menyimpulkan; (2) Masalah atau contoh yang disajikan sebaiknya siswa yang menyelesaikan (seperti pada kegiatan siswa).

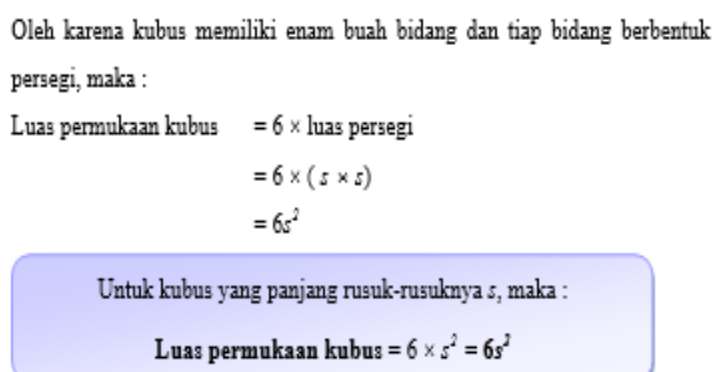

(a)

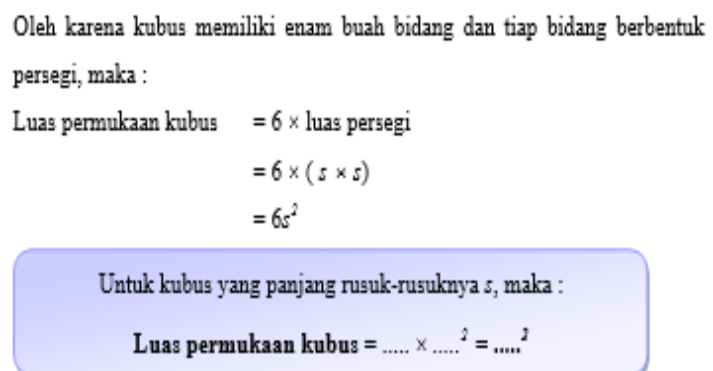

(b)

Gambar 2 (a) Rumus Luas Permukaan Sebelum Divalidasi dan

(b) Rumus Luas Permukaan Setelah Revisi 
2. Joshua ingin membuat sebuah kerangka aquarium berbentuk balok dengan menggunakan alumunium. Aquarium tersebut nantinya akan ia berikan kepada ayahnya yang gemar memelihara ikan hias. Kerangka tersebut berbentuk balok dengan ukuran $3 \mathrm{~m} \times 2 \mathrm{~m} \times 50 \mathrm{~cm}$. Jika harga alumunium $\mathrm{Rp} 30.000,00$ per meter, maka biaya yang diperlukan untuk membuat kerangka aquarium tersebut adalah....

Penyelesaian

Diketahui

- Panjang $(p)=3 \mathrm{~m}$; lebar $(l)=2 \mathrm{~m}$; tinggi $(t)=50 \mathrm{~cm}=0,5 \mathrm{~m}$

- Harga alumunium per meter $=\mathrm{Rp} 30.000,00$

Ditanyakan : Biaya yang diperlukan untuk membuat kerangka aquarium? Jawab :

- Banyak rusuk untuk panjang (p) balok $=4$ buah

- Banyak rusuk untuk lebar $(l)$ balok $=4$ buah.

- Banyak rusuk untuk tinggi $(t)$ balok $=4$ buah

- Panjang total kerangka balok

$=(4 \times p)+(4 \times l)+(4 \times t)$

$=(4 \times 3)+(4 \times 2)+(4 \times 0,5)$

$=12+8+2$

$=22 \mathrm{~m}$

- Biaya yang diperlukan untuk membuat kerangka aquarium :

$=22 \mathrm{~m} \times \operatorname{Rp} 30.000,00$

$=\operatorname{Rp} 660.000,00$

Jadi, biaya yang diperlukan untuk membuat kerangka aquarium adalah $\mathrm{Rp}$ $660.000,00$
2. Joshua ingin membuat sebuah kerangka aquarium berbentuk balok dengan menggunakan alumunium. Aquarium tersebut nantinya akan ia berikan kepada ayahnya yang gemar memelihara ikan hias. Kerangka tersebut berbentuk balok dengan ukuran $3 \mathrm{~m} \times 2 \mathrm{~m} \times 50 \mathrm{~cm}$. Jika harga alumunium $\mathrm{Rp} 30.000,00$ per meter, maka biaya yang diperlukan untuk membuat kerangka aquarium tersebut adalah....

Penyelesaian

Diketahui

- Panjang $(p)=3 \mathrm{~m}$; lebar $(l)=2 \mathrm{~m}$; tinggi $(t)=50 \mathrm{~cm}=0,5 \mathrm{~m}$

- Harga alumunium per meter $=\mathrm{Rp} 30.000,00$

Ditanyakan : Biaya yang diperlukan untuk membuat kerangka aquarium? Jawab :

- Banyak rusuk untuk panjang (p) balok $=4$ buah

- Banyak rusuk untuk lebar $(l)$ balok $=\ldots . .$. buah

- Banyak rusuk untuk tinggi ( $t$ ) balok $=\ldots .$. buah.

- Panjang total kerangka balok

$=(4 \times p)+(4 \times l)+(4 \times t)$

$=(4 \times \ldots .)+.(4 \times \ldots .)+.(4 \times \ldots .$.

$=\ldots .+\ldots .+\ldots .$.

$=\ldots . \mathrm{m}$

- Biaya yang diperlukan untuk membuat kerangka aquarium :

$=\ldots . . \mathrm{m} \times \mathrm{Rp} 30.000,00$

$=R p$.

Jadi, biaya yang diperlukan untuk membuat kerangka aquarium adalah $R p$

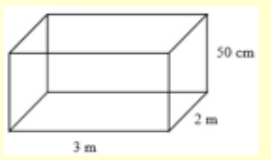

, biaya ya

(a)

(b)

\section{Gambar 3 (a) Contoh Soal Sebelum Divalidasi dan (b) Contoh Soal Setelah Revisi}

Selain dimanfaatkan sebagai bahan ajar yang digunakan oleh guru dan siswa di sekolah, LKS yang dikembangkan juga dimanfaatkan untuk mengembangkan karakter yang baik dalam diri siswa. Wibowo (Asriani, dkk., 2017) menyatakan bahwa bahan ajar perlu ditambahkan nilai pendidikan karakter (akhlak mulia) dan materi ajar dengan cara mengadaptasi kegiatan belajar siswa yang bersifat memfasilitasi dikenalnya nilai-nilai, disadari pentingnya nilai-nilai, dan diinternalisasinya nilai-nilai. Sehingga, pendidikan karakter tidak cukup hanya diimplementasikan dalam mata pelajaran saja, tetapi juga dapat dimasukkan ke dalam bahan ajar yang digunakan.

Hasil penilaian siswa terhadap aspek karakter yang terdapat dalam angket respons pada saat uji coba dapat dilihat pada Tabel 1. Hasil penilaian siswa terhadap aspek karakter dalam angket respons diperoleh rata-rata persentase indeks sebesar $87,96 \%$ dengan kriteria sangat praktis. Kemudian, penilaian guru terhadap aspek karakter yang terdapat dalam angket respons dapat dilihat pada Tabel 2. 
Tabel 1 Hasil Angket Respons Siswa Berdasarkan Aspek Karakter

\begin{tabular}{clcc}
\hline No. & \multicolumn{1}{c}{ Pernyataan } & Persentase & Keterangan \\
\hline 1. & $\begin{array}{l}\text { Kegiatan siswa dan contoh soal dalam } \\
\text { lembar kerja siswa ini memuat } \\
\text { pendidikan karakter. }\end{array}$ & $87,74 \%$ & Sangat Praktis \\
2. $\begin{array}{l}\text { Beberapa soal-soal yang disajikan } \\
\text { memuat pendidikan karakter. }\end{array}$ & $87,74 \%$ & Sangat Praktis \\
3. $\begin{array}{l}\text { Kata-kata motivasi dalam lembar kerja } \\
\text { ini dapat menuntun saya untuk } \\
\text { berkarakter baik. }\end{array}$ & $88,39 \%$ & Sangat Praktis \\
\hline & \multicolumn{1}{c}{ Rata-Rata } & Sangat Praktis \\
\hline
\end{tabular}

Tabel 2 Hasil Angket Respons Guru Berdasarkan Aspek Karakter

\begin{tabular}{clccc}
\hline No. & \multicolumn{1}{c}{ Pernyataan } & Skor & Persentase & Keterangan \\
\hline 1. & $\begin{array}{l}\text { Kegiatan siswa dan contoh soal } \\
\text { dalam lembar kerja siswa ini } \\
\text { memuat pendidikan karakter. }\end{array}$ & 4 & $80 \%$ & Praktis \\
2. $\begin{array}{l}\text { Beberapa soal-soal yang } \\
\text { disajikan memuat pendidikan } \\
\text { karakter. }\end{array}$ & 4 & $80 \%$ & Praktis \\
3. $\begin{array}{l}\text { Kata-kata motivasi dalam lembar } \\
\text { kerja ini dapat menuntun siswa } \\
\text { untuk berkarakter baik. }\end{array}$ & 4 & $80 \%$ & Praktis \\
\hline \multicolumn{1}{c}{ Rata-Rata } & $\mathbf{4}$ & $\mathbf{8 0 \%}$ & Praktis \\
\hline
\end{tabular}

LKS yang dikembangkan memuat pendidikan karakter yang terdapat pada petunjuk kegiatan siswa dan uji kompetensi, contoh soal, serta beberapa soal pada uji kompetensi. Hal tersebut sesuai dengan hasil penelitian Manisa, dkk. (2018) yang menyimpulkan bahwa siswa memberikan respons positif terhadap LKS yang dikembangkan dengan rerata persentase sebesar 78\%. Pendidikan karakter juga disajikan dalam bentuk kalimat motivasi. Pendidikan karakter ditujukan untuk menuntun siswa dalam mengembangkan karakter yang baik melalui LKS yang digunakan. Nilai karakter yang terdapat dalam LKS yang dikembangkan adalah bertanggung jawab, jujur, kerja keras, dan disiplin.

\section{SIMPULAN}

Berdasarkan hasil analisis data penelitian, dapat disimpulkan bahwa: (1) Penelitian yang dilakukan menghasilkan bahan ajar berupa LKS berbasis 
pendidikan karakter yang memenuhi tingkat kevalidan dengan rata-rata skor penilaian validator sebesar 95,70\% dengan kriteria sangat valid; dan (2) Penelitian yang dilakukan menghasilkan bahan ajar berupa LKS berbasis pendidikan karakter yang memenuhi tingkat kepraktisan dengan rata-rata skor angket respons siswa sebesar $89,08 \%$ dengan kriteria sangat praktis dan angket respons guru sebesar $85,56 \%$ dengan kriteria sangat praktis.

\section{DAFTAR PUSTAKA}

Annisa, S. 2017. Pengembangan Lembar Kerja Siswa Berbasis Model Pembelajaran Kooperatif pada Mata Pelajaran Keterampilan Komputer dan Pengelolaan Informasi (KKPI). Jurnal Jaringan Sistem Informasi Robotik, 1(1): 8-17.

Arahim, I. A. 2018. Pengembangan Lembar Kerja Siswa dengan Visualisasi Berbantu Macromedia Flash pada Pembelajaran Matematika. Edukasi: Jurnal Pendidikan, 16(1): 116-123.

Asriani, P., Sa'dijah, C., \& Akbar, S. 2017. Bahan Ajar Berbasis Pendidikan Karakter untuk Siswa Kelas IV Sekolah Dasar. Jurnal Pendidikan: Teori, Penelitian, dan Pengembangan, 2(11): 1456-1468.

Fadillah, S. 2013. Pembentukan Karakter Siswa Melalui Pembelajaran Matematika. Jurnal Pendidikan Matematika PARADIKMA, 6(2): 142-148.

Farapatana, E., Anwar, Y. S., \& Abdillah. 2019. Pengembangan Komik Matematika dengan Metode Preview, Question, Read, Reflect, Recite, \& Review (PQ4R) pada Materi Lingkaran Kelas VIII SMP. Jurnal Teori dan Aplikasi Matematika, 3(1): 1-6.

Fathurrohman, Puguh, Suryana, \& Fatriany, F. 2017. Pengembangan Pendidikan Karakter. Bandung: Refika Aditama.

Kesuma, M. Y. S. A. 2018. Pengaruh Implementasi Pendidikan Karakter, Motivasi Belajar, dan Perhatian Orang Tua terhadap Prestasi Belajar Siswa pada Mata Pelajaran Perbankan Dasar Siswa Kelas X Akutansi SMK Muhammadiyah 1 Yogyakarta Tahun Ajaran 2017/2018. Skripsi pada Universitas Negeri Yogyakarta: tidak diterbitkan.

Khairunnisa. 2016. Pengembangan LKS Berbasis Problem Based Learning Bermuatan Sikap Spiritual pada Materi Pengukuran untuk Meningkatkan Kemampuan Berpikir Kritis Siswa. Jurnal Ilmiah Mahasiswa (JIM) Pendidikan Fisika, 1(4): 284-291.

Manisa, T., Aryati, E., \& Marlina, R. 2018. Respon Siswa terhadap LKS Berbasis Inkuiri Terbimbing pada Submateri Sistem Pernapasan Manusia Kelas XI. Edukasi: Jurnal Pendidikan, 16(1): 1-10.

Nuhamara, D. 2018. Pengutamaan Dimensi Karakter dalam Pendidikan Agama Kristen. Jurnal Jaffray, 16(1): 95-115.

Ramadhani, R. 2017. Peningkatan Kemampuan Pemecahan Masalah Matematika Ditinjau dari Gender Melalui Pembelajaran Berbasis Masalah Berkarakter 
pada Siswa Kelas XI SMA YPK Medan. Jurnal Edukasi Matematika, 8(15): 924-932.

Harahap, Z. H. 2017. Pendidikan Karakter Berbasis Nilai Moral dan Nilai Kebangsaan. Prosiding Seminar Nasional Tahunan Fakultas Ilmu Sosial Universitas Negeri Medan, Medan: Hal. 407-410.

Riskawati, Duwi, Buyung, \& Yarmayani, A. 2018. Pengembangan Lembar Kerja Siswa (LKS) Berbasis Penemuan Terbimbing pada Materi Bangun Ruang Sisi Lengkung Siswa Kelas IX SMPN 31 Kab. Tebo. Jurnal Pendidikan Matematika, 2(1): 111-118.

Sugiana, A. 2019. Penanaman Nilai Karakter Disiplin dan Tanggung Jawab di SMK Ethika Palembang. Jurnal PAI Raden Fatah, 1(1): 105-116.

Sumartini, T. S. 2015. Peningkatan Kemampuan Penalaran Matematis Siswa Melalui Pembelajaran Berbasis Masalah. Jurnal Pendidikan Matematika, 5(1): $1-10$.

Wahyuni, I. 2017. Pengembangan Media Booklet Bermuatan IDEAL Problem Solving dalam Materi Balok terhadap Kemampuan Pemecahan Masalah Matematis pada Siswa Kelas VIII SMP Bina Utama Pontianak. Skripsi pada IKIP PGRI Pontianak: tidak diterbitkan.

Widyaningrum, N. 2018. Pengembangan Lembar Kerja Siswa (LKS) Berbasis Problem Based Learning Bermuatan Karakter untuk Meningkatkan Kemampuan Pemecahan Masalah dalam Materi Statistika pada Siswa Kelas IX SMP Negeri 1 Meliau. Skripsi pada IKIP PGRI Pontianak: tidak diterbitkan. 